\title{
PREVENTION OF DRUGS ABUSE BY IMPROVING ENTREPRENEURIAL SKILLS
}

\author{
Mochamad SOELTON ${ }^{*}$, Eko Tama Putra SARATIAN ${ }^{2}$, Nur Endah Retno WURYANDARI ${ }^{3}$, \\ Lisnatiawati SARAGIH ${ }^{4}$, Made SETINI ${ }^{5}$, Anees Janee ALI ${ }^{6}$, and Agus ARIJANTO ${ }^{7}$ \\ 1,2,4,7Universitas Mercu Buana \\ ${ }^{6}$ USOM Universiti Sains Malaysia \\ ${ }^{5}$ Udayana University \\ ${ }^{3}$ Dian Nusantara University \\ *soelton@mercubuana.ac.id
}

\begin{abstract}
Drug abuse and illicit trafficking is a complex problem, both causative and related factors. The countermeasures require a multidisciplinary approach, as well as integration across government sectors, as well as the integration of all parties, as well as the role of commitment and the entire community. In this regard, to determine the extent of public understanding and understanding of drugs, there is a positive relationship between improving the quality of human life and its maintenance. Society as a whole and the interaction between the two, it is necessary to empower the community through improving the quality and capacity of human resources in the context of preventing and overcoming drug trafficking. There are many creative ways to invite people to preventing drugs. One of the things that can be maximized is creativity and local wisdom such as urban farming as a medium for drug prevention. The Participants knowledge before socialization can be identified from the pre-test activities, most of which $60 \%$ have less knowledge about drugs and $70 \%$ have less knowledge about urban farming. while after socialization the post-test results are mostly good $90 \%$ regarding the types of drugs and the impact of drug abuse compared to those with good knowledge regarding urban farming 95\% The results of the activity showed that the youth organization had understood the dangers of drugs abuse for their character building. In addition, they were eager to be entrepreneur regarding urban agriculture. The Education Institution such as Universitas Mercubuana together with the local government seeks to empower the community, especially in areas prone to illicit drug trafficking, so as not to fall into the illicit business by providing training and entrepreneurial skills so that people in the area are able to live independently and have a stable economy.
\end{abstract}

Keywords: Economy, Character Building, Drugs, Entrepreneur

\section{BACKGROUND}

The prevalence of the death rate caused by narcotics abuse reaches 12,044 people per year and puts Indonesia in an emergency position. Insufficient information about the types and impacts of drugs has contributed to the increase in the prevalence of drug abuse. Community participation in the form of socializing the impact of drug abuse in the community is one of the comprehensive countermeasures.

In the 2020 UNODC World Drug Report, it is recorded that around 269 million people in the world abuse drugs (study in 2018). This number is $30 \%$ more than in 2009 with the number of drug addicts recorded at more than 35 million people (third booklet of the World Drugs Report, 2020). UNODC also released a global phenomenon where as of December 2019 it was reported that more than 950 types of new substances had been discovered. Meanwhile in Indonesia, based on data from the National Narcotics Agency (BNN) Laboratory, so far, 83 NPS have been detected, of which 73 NPS are included in Permenkes No. 22 of 2020.

Drug trafficking and abuse is one of the national problems that is considered serious by the government, because it can cause damage to the nation's morale. Therefore, the government pays great attention to the handling of drug abuse. In our country, the problem of widespread drug abuse is increasing. The domino effect resulting from drug abuse is also increasingly diverse, and efforts to overcome drug abuse are steps that are not easy to implement. Abusers are people who use Narcotics without rights or against the law. When someone abuses Narcotics continuously, that person will be in a state of dependence on Narcotics, both physically and psychologically. Narcotics dependence is a condition characterized by an urge to use Narcotics continuously with increasing doses to produce the same effect and when its use is reduced and/ or stopped suddenly it causes characteristic physical and psychological symptoms.

Drug abuse and illicit trafficking is a complex problem, both causative and related factors. The countermeasures require a multidisciplinary approach, as well as integration across government sectors, as well as the integration of all parties, as well as the role of commitment and the entire community. In this regard, to determine the extent of public understanding and understanding of drugs, there is a positive relationship between improving the quality of human life and its maintenance. Society as a whole and the interaction between the two, it is necessary to empower the community through improving the quality and capacity of human resources in the context of preventing and overcoming drug trafficking

Drug abuse is caused by several factors that influence each other, namely: 1) the geographical location of Indonesia; 2) Economic factors; 3) Difficulty in obtaining medication; 4) Family and community factors; 5) Personality factor; 6) The physical factor of the individual who abuses it.

The economic impact felt by the Indonesian people during the Covid-19 pandemic began to have an impact in various regions. The number of companies that lay off their workers has an impact on many families, but there are also many people who still exist because they are 
able to create independent businesses that are sufficient to support the family's economy. The Education Institution such as Universitas Mercubuana together with the local government seeks to empower the community, especially in areas prone to illicit drug trafficking, so as not to fall into the illicit business by providing training and entrepreneurial skills so that people in the area are able to live independently and have a stable economy.

The drug dependence can be interpreted as a condition that encourages someone to take illegal drugs repeatedly or continuously. If someone does not use it, he will feel addicted (sakau) which results in an even uncomfortable feeling. Even worse he will have the feeling of pain (Joseph, 2004).

According to Siswanto Sunarso (2010) ignorance of the younger generation on drugs as well as personality fluctuations and availability Drugs are the main problem in the fight against drugs or narkotics. By hence, the supply variable with requests must be handled at once.

Besides that, the impact of narcotics abuse according to the National Narcotics Agency (2010), narcotics can be divided into 3 types, namely:

1. Depressant, that is something which suppresses the central nervous system and reduces the functional body so that the user feels numb; it can even make the users to be asleep and self-defeats. When overdosed, it can lead to death. The depressant drug types include opioda, various derivatives such as morphine, and heroin. The present popular example is the Putaw.

2. Stimulants, something which stimulates body functions and increase excitement as well as awareness. Stimulant types include: Caffeine, Cocaine, and Amphetamine. The examples that are now often used are the Shabu and the Ecstasy.

3. Hallucinogens, the main effect of which is changing the perspective or having hallucinations. The hallucinogens mostly come from the plants such as mescaline which is from cactus and psilocybin which is from mushrooms. In addition there are also those that are mixed in the laboratory such as the LSD. The most widely used is marijuana.

Dealing with abuse problems drugs require cooperation from the parties government and society. There are five forms ways to deal with abuse drugs, namely: promotive, preventive, curative, rehabilitative and repressive (Hanifah dan Unayah, 2011).

Narcotics, Psychotropics and other Addictive Substances (Drugs) which are commonly called narcotics are a type of drug necessary drugs/substances. Narcotics and psychotropics is a drug or material that is useful in the field of treatment, health services, and development science, and on the other hand can create a very detrimental dependence if used without control, supervision strict and thorough (Yamin, 2012).

From the formulation of the main problem, the importance of the following issues is explained:
1. The Importance of Basic Understanding of the Definition, the Types and the Impact of Drugs

The basic understanding of the meaning of drugs and their types and their impact on the younger generation as the hope of the nation and the state is very important and urgent. Narcotics is an abbreviation of the narcotics, the psychotropic substances, and the addictive substances. Drugs are medicine, the ingredients, the substances that are drunk / smoked / swallowed, or injected and it can cause dependence and affect the work of the brain, as well as the vital functions of other organs (the heart, the blood circulation, the breathing, etc.) Narcotics are substances or drugs derived from plants or non-plants, both synthetic and semisynthetic which cause a decrease or change in consciousness and eliminate or reduce the pain and they can cause dependence (Law No.27 / 1997) Meanwhile, according to $\mathrm{WHO}$ what is meant by the definition of this drug definition is a substance which, if inserted into the body, will affect physical and / or psychological function (except food, water, or oxygen).

The danger of drugs for the addicts (young generation) is very much and if it is not immediately stopped the habit of consuming drugs, this will worsen the health status of the users themselves slowly but surely, and certainly it can endanger the survival of this nation in the future. Youth as a generation that is expected to be the nation's successor, the more fragile the day is undermined by the addictive substances of neurological destruction, so that the young man cannot think clearly. As a result, the generation of hope for a strong and intelligent nation will only remain a memory. The target age of drug users is the student age, which ranges from 11 to 24 years. This indicates that the dangers of drugs can target our students at any time. The effects of drug use can be in various forms, including the following: 1) Causing a decrease or even change in consciousness, 2) Eliminating the senses, 3) Reducing to relieve pain, 4) Adding dependency / addiction. The greatest danger of drugs for health is the effect of the drug dependence itself. Because with the bad effects caused to drug addicts is the desire to always use it repeatedly.

2. The importance of knowing "Entrepreneurial Skill" in the Early Prevention of Drug Abuse Efforts

The values of life that are given are the character and the good character building programs that are integrated with the entire learning process of the students, starting from their home, their school, their extra-curricular activities, their social activities, and other self-development activities. The value education will perfect the formal education of the students get through the transfer of the knowledge and the skills in school.

It is increasingly recognized that the transfer of knowledge and skills for the students without prioritizing value transfer will only give birth to the students who are skillfully cognitive and skillful, but their fundamental 
weaknesses in interpreting and applying life values, including: the importance of respect for the parents and the teachers, respect for older people, the discipline, the enthusiasm for learning, the identity, the future vision, the achievement motivation, the cooperation, the willingness to help others, the self-integrity, and a number of other positive characters needed for success.

In building a value-based school culture that is the central mission of the education at this time, various approaches to character and character education are needed, both with those that are integrated with the student learning curriculum and with the specific approaches that are given with certain methods. Specific approaches with certain methods are carried out in the form of training using the experiential learning methods. This motivational seminar given to SMK PGRI 5 Pegadungan, Kalideres, West Jakarta students was a stimulus, and became meaningful when the students who took part in the training were committed to practicing it in the study and the daily life. Therefore, this value training was designed in such a way as to help students who were trained to have a strong reflective attitude from every action in the learning process experienced, both at school, in the family, in the social environment, in the community, within the nation, and the country.

This value building training in the character building used a heroic leadership approach based on the four pillars, namely: self-awareness, responsiveness, love, and a burning spirit.

The impact of narcotics abuse on a person depends on the type of narcotics that is used and it will influence the personality of the user and the situation or condition of the user.

In general, the impact of narcotics addiction can be seen in a person's physical, psychological, and social condition.

Physical impact:

1. Disorders of the nervous system (neurological) such as: convulsions, hallucinations, impaired consciousness, and peripheral nerve damage.

2. Disorders of the heart and the blood vessels (cardiovascular) such as: acute infection of the heart muscle, and the circulatory disorders.

3. Skin disorders (dermatological) such as: landings (abscesses), allergies, and eczema.

4. Disorders of the lungs (pulmonary) such as: suppression of respiratory function to difficulty breathing, and hardening of the lung tissue.

5. Frequent headaches, nausea and vomiting, stiffness, increased body temperature, liver wasting, and difficulty sleeping.

6. Impacts on the reproductive health are endocrine disorders, such as: decreased function of reprouduction hormones (estrogen, progesterone, testosterone), and sexual dysfunction.

7. Impacts on the adolescent reproductive health include changes in menstrual periods, menstrual irregularities, and amenorhoe (no menstruation).
8. For the drug users through needles, especially for sharing needles and syringes, the risk is contracting diseases such as hepatitis B, C, and HIV which until now it has no cure.

9. Drug abuse can be fatal when there is an Over Dose that is the drug consumption that exceeds the body's ability to receive it. Over doses can cause death

Psychic Impact:

1. Being Lazy learning, careless, often tense and nervous

2. Losing self-confidence, apathy, fantasy, and suspicion

3. Being agitative, becoming violent, and being brutal behavior

4. Having difficulty concentrating, feeling upset and feeling depressed

5. Having the tendency to hurt yourself, feeling insecure, even commiting suicide

Social Impact:

1. Mental, anti-social and immoral disorders, being isolated by the environment

2. Troubling and becoming a family burden

3. Disrupted education and having a gloomy future.

Physical, psychological, and social impacts are closely related.

The physical dependence will result in tremendous pain (withdrawal) in the event of a drug breakdown (not taking drugs on time) and the psychological encouragement in the form of a very strong desire to consume. These physical and psychological symptoms are also related to social symptoms such as the urge of deceiving parents / friends, stealing, being angry, being manipulative, and others.

\section{METHOD}

There are many creative ways to encourage people to stay away from drug abuse. One of the things that can be maximized is exploring creativity and local wisdom as a medium for preventing drug abuse. The implementation of the community service program at the Karang Taruna RW.007 North Kembangan, Kembangan District went well. The community service program is in the form of online seminars/webinars on marketing management and promotion of organic products from urban areas or urban agriculture using Information Technology. Karang Taruna cadres who attend training to conduct business development and marketing of urban farming products using information technology through social media and marketplaces and can find various information as well as learning tools that can also be taught in the future can be applied in everyday life the days and every activity carried out by Karang Taruna.

Learning is carried out online using video conferencing (Zoom and Google meet) and using the experiential learning method with interactive commu- 
nication techniques through video conferencing, dialogue, discussion, role play / games, where participants are introduced provide understanding the importance of youth awareness (adolescents) in self-prevention the influence of drugs. Practically, this activity is useful for reducing numbers drug use in young people.

This online learning was held in collaboration with the Faculty of Economics and Business, Mercu Buana University (UMB) with Youth organizations located in the West Jakarta area district North Kembangan. UMB helped provide speakers, learning equipment, webinar flyers, pre-post examinations, evaluations, while the organisation helped send representatives of youth members groups. Online learning participants are 78 participants in this activity.

Phase 1: Participant's initial test and initial assessment After the opening ceremony and before the material was delivered, participants were asked to fill in the questionnaire using google form as a preliminary test. Initial assessment of the participants is done by filling out the online learning registration form.

Phase 2: Submission of online learning material by the instructor

The online learning material consists of presentations of Complexity Regarding Drugs and the Impact of Abuse and Nation and Personal Character Building as a Model and Strategy to Prevent Drug Abuse. And regarding the Utilization of Information and Communication Technology in the Management of Urban Agricultural Products or Urban Farming

Phase 3: Post-test and feedback

Before closing, participants are asked to fill in a posttest, and evaluate the event, messages, and impressions of the participants as feedback using google form.

\section{RESULTS AND DISCUSSION}

In general, the results of the community service activities can be seen based on the following components:

1. The success of the target number of e-learning participants. The success of the target number of e-learning participants can be said to be very good. The target number of training participants is 100 people and in the implementation of the service, 78 people (78\%) are attended. This is supported by the role of Youth group organization or Karang Taruna North Kembangan starting from the preparation, distribution of invitations.

2. Participants knowledge before socialization can be identified from the pre-test activities, most of which $60 \%$ have less knowledge about drugs and $70 \%$ have less knowledge about urban farming. while after socialization the post-test results are mostly good $90 \%$ regarding the types of drugs and the impact of drug abuse compared to those with good knowledge regarding urban farming $95 \%$.

3. Achievement of online learning objectives. The achievement of online learning objectives can be said to be good, reaching $95 \%$. This community service activity has succeeded in empowering youth organizations at community service locations by motivating them to carry out various positive activities through the use of information technology to avoid deviant associations, especially related to drug abuse.

4. The ability of participants in mastering the material. The ability of participants in mastering the material can be said to be very good $(95 \%)$. This is because the youth are familiar with information technology, all participants have social media accounts and are supported by the use of lecture and demonstration methods to improve the ability of participants to absorb the material presented by trainers

Most of the socialization activities about the effects of drugs among adolescents and young people that are followed by the community have increased knowledge were considered successful. This success is not only measured by the four components above, it can also be seen from the satisfaction of participants after participating in the online learning activities.

\section{CONCLUSION}

Based on the discussion in the previous chapters, in this community service activity the following conclusions can be drawn:

First, the government cooperates with educational institutions such as universities. The government holds regular meetings with local community leaders and educational institutions such as Universitas Mercubuana; The purpose of the meeting is to provide enlightenment to public figures, both formal and informal, regarding the role of the community in preventing and controlling and eradicating the circulation of illegal drugs as stipulated in the Narcotics Law and the Psychotropic Law. Encourage the process of building public awareness, building systems, developing guidelines, and training community workers. With the development of information and communication technology, today's technological sophistication, it is hoped that the government and educational institutions can create applications that make it easier for the public to access information about drugs, as well as easy access to contact the authorities in reporting if suspected criminal acts related to drug abuse are suspected found. The other benefits of information and communication technology that can be obtained the participants are understandings of urban agricultural using information technology so that they become entrepreneurs in the field of Agribusiness through the Hydroponic method.

Second, the community. The community also has a role to play in the formation of adolescent character building and personality in the process of self-realization. The community is aware of the conditions that allow teenagers to create explore and develop all talents, capacities and potentials self. People can also control the association and know what they are doing in the social group. The 
community must reprimand and also advise youth if actions are found deviate from social norms.

\section{REFERENCE}

Anhari, Ahmad. (2012). "Upaya BNN dalam Pencegahan penyalahgunaan narkoba di Kalangan Remaja”.

Arief, Harefan \& Tama Putra Saratian, Eko. (2018). ENTREPRENEURIAL OPPORTUNITIES IN INDONESIA TO INITIATE BUSINESS THROUGH IMPORTER COMMUNITIES. ICCD. 1. 446-454. 10.33068/iccd.Vol1. Iss1.66. (16) (PDF) DEVELOP LEADERSHIP, MANAGEMENT AND PERFORMANCE ORGANIZATIONONINTRA-SCHOOL STUDENT ORGANIZATION (OSIS). Available from: https:// www.researchgate.net/publication/337699277 DEVELOP_LEADERSHIP_MANAGEMENT_ AND_PERFORMANCE_ORGANIZATION ON_IN T R A - S C H O O L_S T UDEN T ORGANIZATION_OSIS [accessed Jun 24 2021].

Baker, S. R., Bloom, N., Davis, S. J., \& Terry, S. J. (2020). Covid-induced economic uncertainty (No. w26983). National Bureau of Economic Research.

Humas BNN, (2020). "BNN RI Beri Pelatihan Bisnis Halal Di Daerah Rawan Narkoba” https://bnn.go.id/ bnn-ri-beri-pelatihan-bisnis-halal-daerah-rawan/

Fitri M, \& Migunani S. 2014. Sosialisasi dan Penyuluhan Narkoba. Jurnal Inovasi dan Kewirausahaan, 3(2): $72-76$
Hanifah, Abu dan Nunung Unayah, (2011). "Mencegah dan Menanggulangi Penyahgunaan Napza Melalui Peran Serta Masyarakat". Informasi, Vol. 16 No. 01 Tahun 2013. https://media.neliti.com/ media/publications/52830-ID-mencegah-danmenanggulangipenyalahgunaa.pdf

M Soelton, T Nugrahati, Y Ramli, D Permana, D Kurniawan (2018). TOWARD THE BEST STRATEGY IN MINIMIZING THE SPREAD OF DRUG USERS. Proceedings International Conference and Community Development 2018. 1 (1), 171-176

Soelton, M., Arief, H., Ramli, Y., Setiawan, M., Rohman, F., \& Mugiono, M.(2019,). THEBEST STRATEGY FOR FORMING CHILDCARE FROM AN EARLY AGE. In ICCD (Vol. 2, No. 1, pp. 277-280).

Sunarso,Siswanto. 2010. Penegakan Hukum Psikotropika: Dalam Kajian Sosiologi Hukum, Jakarta: PT. Rajagrafindo Perkasa

Yamin, Muhammad. (2012). Tindak Pidana Khusus. Cetakan Pertama. Bandung: Pustaka Setia

Yan, Jun \& Yan, Li (2016). "Individual Entrepreneurship, collective entrepreneurship and innovation in small business: an empirical study". International Entrepreneurship and Management Journal, Vol 12: 1053-1077. 